\title{
An Archaeology of Affect: Art, Ontology and the Carved Stone Balls of Neolithic Britain
}

\section{Andrew Meirion Jones ${ }^{1}$}

Published online: 3 July 2020

(C) The Author(s) 2020

\begin{abstract}
This paper aims to shift debate in the study of archaeological art away from epistemological questions of definition towards ontological approaches. To this aim, the paper proposes a non-representational study of archaeological art based on the twin concepts of affect and agential intra-action. As an example of this approach, the paper examines the carved stone balls of Neolithic Scotland. The analysis of carved stone balls focuses on their making and on their inter-regional circulation and exchange as a way of approaching the affective character of these artefacts. The paper finishes with a detailed consideration of the concepts of affect and intra-action and advocates their use in the archaeology of art.
\end{abstract}

Keywords Affect · Carved stone ball $\cdot$ Intra-action $\cdot$ Neolithic

This paper examines an unusual group of artefacts from Neolithic Britain: the carved stone balls of Scotland. These small stone spheres are often three-dimensionally sculpted and intensely carved. Extensively circulated on the nineteenth century antiquities market, carved stone balls have long intrigued antiquarians and archaeologists. Carved stone balls might be regarded as stone technologies, yet their intense carving suggests otherwise. Does it make any sense to define these artefacts as examples of "Neolithic art"?

Several recent authors have discussed the definition of art in archaeology. John Robb (2017) surveys the literature on "art" in archaeology and anthropology and proposes that "art" objects be instead considered as "powerful objects"; this proposition raises almost as many objections as the problematic definitions of archaeological "art": what is "power" and how are we to archaeologically legislate on whether an artefact is "powerful" or not? Ylva Sjöstrand (2017) argues for the applicability of the term "art"

Andrew Meirion Jones

amj@soton.ac.uk

1 Archaeology, Faculty of Arts and Humanities, University of Southampton, Highfield,

Southampton SO17 1BF, UK 
in archaeology. Ingeniously, Sjöstrand argues for art as a particular function of particular kinds of artefact. Unfortunately, this proposal appears to reassert a kind of constructivist position in which art is a representational property added to objects.

It is fair to say that definitions of art are slippery. Art is difficult to define in a contemporary context and even more so in a prehistoric setting. Art historian Carolyn Dean (2006) very effectively discusses the problems associated with importing the concept of art to the study of non-Western cultures: a colonial move that renders nonWestern cultures as similar to the West. "The recognition of "art" can be seen as an attempt to reconstruct other visual cultures in the image of the colonizing West, different only in ways that render them insufficient" (Dean 2006, 27). All too often, the study of non-Western visual culture is rendered in the language of art history. Consider, for example, the reconstruction of Yoruba art critical discourse (Fariss Thompson 1973) or the deployment of the art historical concept of aesthetics to discuss the Yolngu bark painting of northeast Arnhem Land, Australia (Morphy 1992).

Carolyn Dean $(2006,32)$ argues that we should guard against the "unreflective usage of modern art history's notions, ideas, terms and tropes." This injunction is particularly acute for the study of prehistoric art, where scholars of prehistoric visual culture have tended to borrow from the intellectual lexicons of art history or the anthropology of art (Porr 2019) to the detriment of a rich understanding of the particularities of the evidence for prehistoric visual practices (see Jones and Cochrane 2018, 12-15). As an alternative, I here adopt a strategy proposed by a much older tradition of art history: that of the American art historian George Kubler (1962). Kubler notes that definitions of art as a kind of symbolic language (still commonplace in archaeology; see e.g. Creese 2017) have forced us to overlook definitions of art as systems of relations (Kubler 1962, ix). In this paper, I adopt Kubler's approach by examining carved stone balls as systems of relations. In particular, I examine affect as a key element of the systems of relations involved in the making and circulation of carved stone balls.

Rather than pursuing an epistemological agenda by attempting to define what art might look like in the context of Neolithic Britain, I instead pursue an ontological approach by considering what making Neolithic carved stone balls achieved (see also Jones 2017; Porr 2019 for the discussion of a similar approach to rock art studies). I do this by developing the concepts of affect and intra-action. I argue that the study of affect offers a genuinely archaeological approach to the study of visual forms and circumvents the necessity to legislate on whether those visual forms constitute "art" in the Western sense.

\section{Materials, Agency, Affect and Intra-Action}

Evaluating the aesthetics qualities, and understanding the meaning of, visual forms has long been part of the intellectual toolkit of art historians and anthropologists. The anthropologist Alfred Gell (1998) has been critical of both approaches. Gell $(1998,6)$ rejected 'the idea that anything, except language itself, has "meaning" in the intended sense.' He was also suspicious of aesthetic analysis: 'I am far from convinced that every "culture" has a component of its ideational system which is comparable to our own "aesthetics"'(Gell 1998, 3). Instead of focusing on meaning and aesthetics he 
argued that artworks were a form of action, a way of acting on and effecting the world. For Gell, the anthropological study of art begins with the study of social relations. Echoing George Kubler's (1962) earlier definition of art as systems of relations, Gell argues that art objects exist in networks of social relations and in certain circumstances "art objects are the equivalent of persons, or more precisely social agents" (Gell 1998, 7). This network of social relationships is described by Gell as the "art nexus" and consists of relationships between artworks, artists, prototypes, patrons and the viewers of artworks (known as "patients" in Gell's scheme). While Gell's relational approach to artworks as actions is very welcome, his argument that artworks are social agents which are the equivalent of persons is problematic. This argument has drawn criticism from a number of quarters. Howard Morphy $(2009,6)$ argues that this is an analogy too far, while Chris Gosden $(2001,164)$ takes issue with Gell's concept of the secondary agency of artworks: "to call objects secondary agents is to make them look like people, but with certain deficiencies of intention."

It is debateable whether Gell's scheme moves us much further than the analysis of meaning and aesthetics that he sought to avoid. We are faced with two options: artworks are made meaningful because of the ideas projected onto materials by artists (the standard view adopted by many art historians and anthropologists), or artworks become agents because they mediate the intentions and social agency of the artist (Gell's view). Neither of these options is particularly helpful and both overlook the material properties of the artwork, and the processes involved in their making (Jones and Cochrane 2018, 21-22). Instead, I argue that the material properties of things have a vital role to play in our understanding of visual forms. Rather than materials being passive conduits for human agency, I argue instead that the interaction (or the intraaction) of materials with artists during making produces certain affects and effects.

To begin to think differently about materials we need to reconsider the concept of agency. The term agency is typically associated with notions of human intention and causality (see e.g. contributions to Dobres and Robb 2000). More specifically, Gell (1998) was concerned to examine agency as a set of transactions in which artworks are viewed as components of the art nexus. At some junctures, agency may be attributed to humans, at other points agency is attributed to the artwork which as a "secondary agent" mediates human agency: "in any given transaction in which agency is manifested, there is a "patient" who or which is another "potential" agent, capable of acting as an agent or being a locus of agency' (Gell 1998, 22, original emphasis). Gell's discussion of agency is then closely allied to questions of causality and representation: who is being represented, how are they being represented (as primary or secondary agents), who is doing the representing, and when? However, discussions of agency need not be concerned with representation, intention and causality as philosopher of science and feminist scholar Karen Barad (2003, 2007) elaborates. For Barad (2013, 54) agency 'is not held, it is not a property of persons or things; rather, agency is an enactment, a matter of possibilities for reconfiguring entanglements'. Barad (2007, 140) proposes that entities (such as materials and humans) do not pre-exist relationships, rather they emerge through specific intra-actions. Whereas the term "interaction" implies action linking pre-existing entities, "intra-action" implies action that connects, entangles and co-constitutes. Therefore, Barad's intra-active account of agency "is about possibilities for worldly re-configurings" (Barad 2013, 55). Barad (2007, 151) insists on the indivisibility between concepts and matter. Rather than thought and 
matter being distinct they are conjoined by intra-active practices in a process she describes as "mattering." Matter is "not a thing but a doing, a congealing of agency."

The concept of intra-action was developed by Karen Barad to understand how scientists study the behaviours of fundamental atomic particles in particle physics. Particle physics seems a long way from the study of the archaeology of art. Nevertheless, I believe that these ideas have a wider resonance for understanding the archaeology of art as long as we recognise that the relationship between materials and makers is pivotal to the archaeological study of art. Much of the archaeology of art has been content to study art or imagery as symbols, overlooking the practices and relationships involved in making art and imagery. These kinds of approaches tend to treat the artwork as a finished entity sutured from the processes of its production, and from ongoing processes of intra-action (for development of this point, see Jones and Cochrane 2018; Back Danielsson and Jones Forthcoming). Instead, I advocate here a four-dimensional approach to ancient imagery that recognises that artworks are never completed but are the result of the artist or maker intra-actively following the forces and flows of materials as they extend over time (see also Jones and Cochrane 2018, 183-92; Ingold 2013, 96). The artwork is not a finished product but remains alive, and intraaction with materials is ongoing and produces certain affects, effects and outcomes. I have now introduced a new term in my discussion: affect. This needs to be explained in more detail.

Affect is one of those words with a multitude of meanings. For many scholars, the multiple character of the term "affect" and the emergence of affect studies as a scholarly endeavour is a cause for celebration (Seigworth 2017, i). I heartily agree with this sentiment, but nevertheless would like to offer some clarity on what I mean by "affect" as it relates to the archaeology of art. Affect is often quite narrowly discussed in archaeological literature in terms of emotion (see e.g. Brady and Bradley 2016; Hamilakis 2013). While affects can be emotive they need not always be so, and I do not intend to restrict the term "affect" to emotion.

Instead I adopt the simple definition of affect offered by Melissa Gregg and Gregory Seigworth $(2010,2)$ : affect is "in many ways synonymous with force or forces of encounter." By using the term affect I foreground the energy brought to the encounter between maker and material, and the energy released from this encounter. While Gregg and Seigworth use the term "force" (rather than energy) to describe affect they acknowledge that affects may also be subtle and emotive as well as forceful and strong. By "affect" I refer to both the "change or variation that occurs when bodies collide or interact," while "affect" is also "the transitional product of these kinds of encounters" (Colman 2005, 11). In the context of art Simon O’Sullivan $(2006,38)$ describes affect in terms of encounter "affect here is understood ... as the effect a given object or practice has on its beholder, and on its beholder's becomings." For the philosopher Gilles Deleuze, who initiated much of the discussion of affect, the task of artists is "to render visible forces that are not themselves visible" (Deleuze 2003 [1981], 40), this process of rendering visible forces in a new medium is a form of affect. Through the rendering visible of forces by material media sensations are realised in materials, and in turn materials may produce sensations (Deleuze and Guattari 2009 [1994], 193). Affect provides the impulse for making works of art, and artworks themselves stimulate sensation and affect. As part of what he describes as mental ecology, Félix Guattari (2000 [1989], 36-40) also discusses the capacity of images to "capture" people, 
particularly if these images are consistently repeated. The ability of images to captivate attention in this way is also a significant component of affect.

In a similar sense, Elizabeth DeMarrais (2017) uses the term affect to discuss the embodied experience and visual impact of making and viewing Andean artefacts. Her analysis privileges the impact of the finished image, whereas here I wish to emphasise the impactfulness of images upon makers as components of what George Kubler (1962) regards as formal sequences. Sequences are open ended, and are related together by what Kubler calls "linked solutions": "the problem disclosed by any sequence of artifacts may be regarded as its mental form, and the linked solutions its class of being" (Kubler 1962, 30). My analysis focuses then on the systems of relations amongst a particular class of artefacts - carved stone balls - and considers how affects shape these system of relations.

While the consideration of affect at first sight seems abstract, intangible and difficult to grasp in the context of archaeology, on the contrary I argue that if we consider the role of affect as an aspect of systems of relations we can instead regard affect as a deeply archaeological concept concerned with the trace of forces of encounter, and how these affects in turn produce further impacts or sensations. Intangible affects are recorded archaeologically by their impact on materials or bodies. At this juncture, I want to reintroduce the concept of intra-action to my discussion of affect. Barad (2003, 824) remarks of intra-action: "Either way, what is important about causal intra-actions is the fact that marks are left on bodies. Objectivity means being accountable to marks on bodies." I would argue that what we study when we study the archaeology of art are precisely marks on bodies or materials. Whether these are marks painted on or incised into rocks in rock art, marks pecked into stone to make sculptural forms in Neolithic Europe, early Egypt or the Ancient Andes or marks formed by the moulding and manipulation of clay to make figurines in Mesoamerica or Palaeolithic and Neolithic Europe. Each of these evinces an affect, the product of an intra-action that has left a mark on materials. Each will in turn produce further affects, which we can detect by their intra-action with other materials.

My presentation of affect here is quite linear: affects provide the impulse for the production of artworks, and in turn artworks produce affects and sensations. However, it is important to realise that affects are multiple, relational and ongoing. In her book Ordinary Affects, the anthropologist Kathleen Stewart $(2007,21)$ describes affect as a set of potentials: "the potential stored in ... things is a networks of transfers and relays." In a similar sense, archaeologists Oliver Harris and Tim Flohr Sørenson (2010, 150) point out that affects are generative and dynamic; as such, they propose that affects are components of a relational "affective field." Importantly, affects are not fixed; they change and arise as materials are encountered and re-encountered afresh.

I will now explore the relational character of affects in an extended analysis of the Neolithic carved stone balls of Scotland.

\section{Carved Stone Balls as Artefacts-in-Process}

The Making a Mark project investigated the portable decorated artefacts of Neolithic Britain and Ireland and used digital imaging techniques (including reflectance transformation imaging and structure-from-motion photogrammetry) to explore the 
character of practices of making and re-making associated with this remarkable visual culture (see Jones and Díaz-Guardamino 2019). Although the project discussed an extensive suite of portable decorated artefacts here I restrict my discussion to a single group of artefacts: carved stone balls.

Carved stone balls are small spherical stone artefacts (most are c. $70 \mathrm{~mm}$ in diameter, though a few are 90-114 mm in diameter). Many are intensely worked and have intricately carved designs on their surfaces. The most common form are six-knobbed balls, carved with distinct knobs or projections. There are also four or three-knobbed forms. Another group of stone balls has multiple knobs or projections, with 10-55 or 70-160 knobs, and these balls have the topological form of berries or other natural fruiting bodies, such as horse chestnut (Aesculus hippocastanum) shells. Because of their curious, and apparently non-functional, character, they have attracted attention from a diverse group of people, including archaeologists, artists, mathematicians and members of the public. Carved stone balls are a source of national pride, and enlarged forms of these artefacts grace public squares in several northeastern towns in Scotland as well as the Scottish capital, Edinburgh.

There are over 400 carved stone balls known (numbers vary in the literature, and new examples are still being found in museum stores and excavations; Marshall 1977, 1983). Their distribution is mainly concentrated in Northeast Scotland (from Caithness in the north to Fife in the south), while there are outlying groups of these artefacts in Orkney, in Argyll and the Western Isles, in northern England (as far south as Yorkshire) and Northern Ireland (with a small number also in the Republic of Ireland). The majority of these artefacts have very poor archaeological contexts (most were uncovered as "stray finds" during agricultural activities) which, until recently, made their precise date a source of debate. However, due to finds of carved stone balls in recent excavations at several Neolithic settlements in Orkney and the Hebrides, we can now be more confident about their date: carved stone balls date from between the 31 st and 28th centuries cal. BC (Jones and Díaz-Guardamino 2019, 103-5).

The enigmatic character of carved stone balls has generated a plethora of interpretations. Some have argued that carved stone balls are stone ball bearings used for shifting megaliths (Ravilious 2010), while the balls have also considered to be bolas (Evans 1897; Todd 2006) or weights (Mann 1915). Some mathematicians have argued that the balls are models of Platonic solids made millennia before Plato (Critchlow 2007; Lawlor 2002), while other mathematicians have disputed this (Reimann 2014; Lloyd 2012). The notion of carved stone balls as models is also captured in artist Jim Pattison's conception of them as "models of mind" (Pattison 2012). A persistent interpretation, first discussed by Gordon Childe after his excavations at Skara Brae, Orkney (Childe 1931, 108) is that the balls are ceremonial artefacts or "insignia of rank." This interpretation has coloured most archaeological discussions since then. Archaeologists have argued that carved stone balls were tokens passed around during the meetings of significant individuals (Marshall 1977, 64), or that they are "symbols of power" (Clarke et al. 1985). One of the most reasoned assessments of these artefacts simply points out the sensual qualities of carved stone balls (MacGregor 1999).

Almost all of the debates surrounding these artefacts have focused on either function or symbolism. In each case, arguments are based on an assumption of intentionality: carved stone balls are either made for a functional purpose or to symbolise something; either an ideal mathematical concept or simply "prestige." We can question these assumptions by considering the making of these artefacts. 
Macroscopic and digital analysis of 282 carved stone balls (comprising roughly 60 $70 \%$ of the known examples) produced interesting results regarding the making of these artefacts. One of the key findings of this research was that there was compelling evidence for incomplete working. This was evident from the substantial number of plain balls (representing the earliest stages of manufacture), and in balls that were discarded at various stages during manufacture. In some cases, the knobs were clearly defined on the surface of carved stone balls, but not worked any further. For example, an unprovenanced ball from Aberdeen Museum (Accession no. 15603) had the edges of the knobs pecked but only partially worked. Again, the ball from Tarves, Aberdeenshire (National Museums Scotland Accession no. X.AS-86) had the knobs marked but not fully carved. Other balls exhibited further stages of working. For example, the ball from Glass, Huntly, Aberdeenshire (Aberdeen Museums Accession no. 15937A) had very shallow interspaces (between the knobs) defined but was not fully worked. An example of evidence for incompletion comes from the ball discovered at Mill of Cromdale, Moray (National Museums Scotland Accession no. X.AS 72) where the knobs are not completely defined and the ball appears to be unfinished. In addition, an unprovenanced example (Aberdeen Museums Accession no. 16258) also has the knobs marked out by fine pecking, but otherwise unworked (Fig. 1).

Other balls seem to be in an intermediate state of working, including the example from Kintore, Aberdeenshire (Aberdeen Museums Accession no. 16252) which has a large raised area remaining in one of the interspaces. Surprisingly, one of the balls that appears to be incomplete is one of the most well-known examples: the ball from Glass Hill, Towie (National Museums Scotland Accession no. X.AS 10). While most of the knobs of this ball are finely decorated, one knob remains undecorated. Given the fine working on the rest of this artefact, it seems likely that the undecorated knob was left deliberately unworked.

In several cases, carved stone balls seem to have been revised during working. A good example of this is a knobbed ball from Clatchard, Newburgh, Fife (National Museum Scotland Accession no. X.AS-042) which exhibits evidence for revision during working in the form of peck marks cross-cutting the grooves cut into the surface

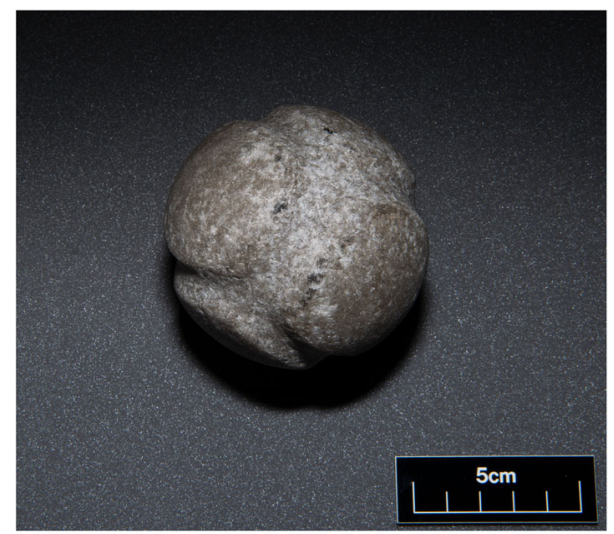

Fig. 1 Unprovenanced carved stone ball with the edge of the knobs reworked by pecking. Photo: Marta DíazGuardamino. Copyright: Marischal Museum, Aberdeen 
of the knobs (Fig. 2); these suggest that the organisation of the design was revised during the process of manufacture.

These artefacts have been classified into distinctive types by previous generations of archaeologists (see Marshall 1977, 1983). The re-analysis presented here suggests that rather than thinking of these artefacts as distinct types the various forms are in fact stages in an operational sequence (see Fig. 3) or chaîne opératoire which works something like this:

- The sequence begins by roughly pecking a sphere from stone, at which point the size of the ball is determined.

- The next stage involves two major options: either divide the sphere with the outline of a series of "knobs" (this produces Marshall's types 1, 2, 4a); or divide the sphere with multiple divisions making multi-knobbed forms (this produces Marshall's types 7 and 8).

- After this, the interspaces between the "knobs" are carved.

- Following this, the interspaces may be worked further to create distinctive "knobs" standing proud of the ball (this produces Marshall's types 1, 2 or 4b)

- In some cases, the interspaces themselves may be decorated, although this is rare.

- Finally, the "knobs" may be decorated or carved further (described by Marshall as type 9).

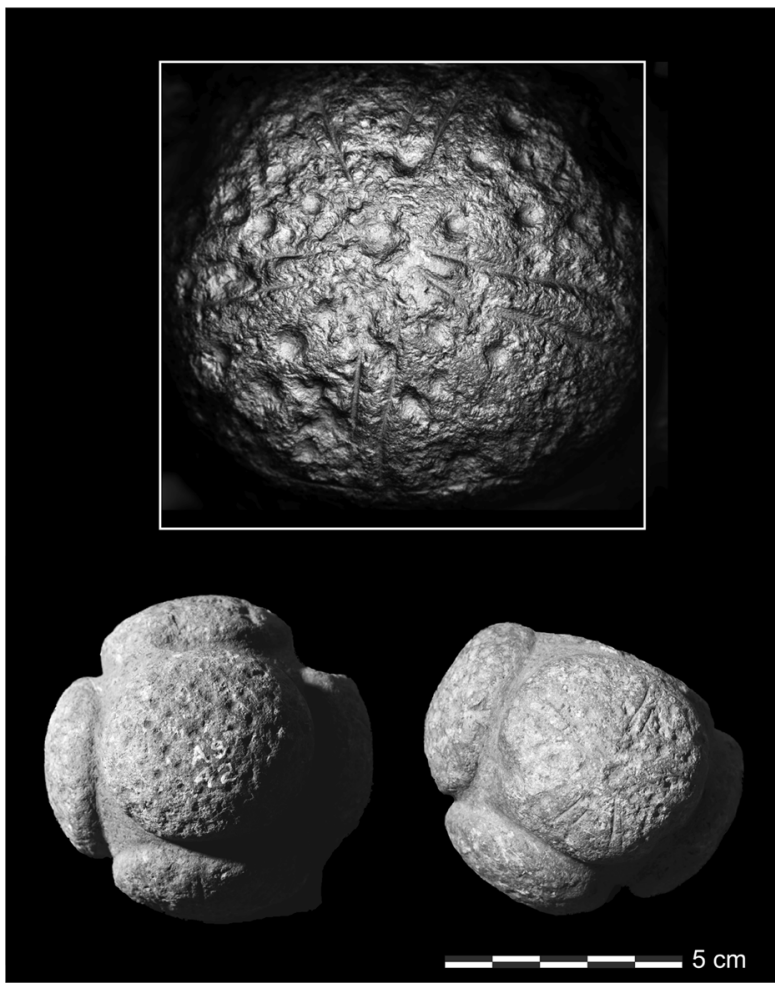

Fig. 2 RTI of the carved stone ball from Clatchard, Newburgh, Fife. Image: Marta Díaz-Guardamino. Copyright: National Museums Scotland 
My analysis of the making of carved stone balls enables us to begin to view these artefacts differently. Rather than viewing this sequence as a series of imposed hylomorphic choices (see Ingold 2013 for a fuller discussion of hylomorphism), my analysis suggests that forms instead emerge through a process of dialogue with materials (see also Jones Forthcoming). What we observe is a sense that carved stone balls take shape through a process of working, as the craftsperson engages with material. If carved stone balls simply served a functional purpose, or were destined to be symbols of prestige, it seems extremely unlikely that they would be discarded in an unfinished state. Carved stone balls emerge through an ongoing process of working, an unknowing, that may produce very fine forms, or may result in carved stone balls being discarded during the process of working. It seems doubtful that we can regard

\section{MAKING A CARVED STONE BALL}

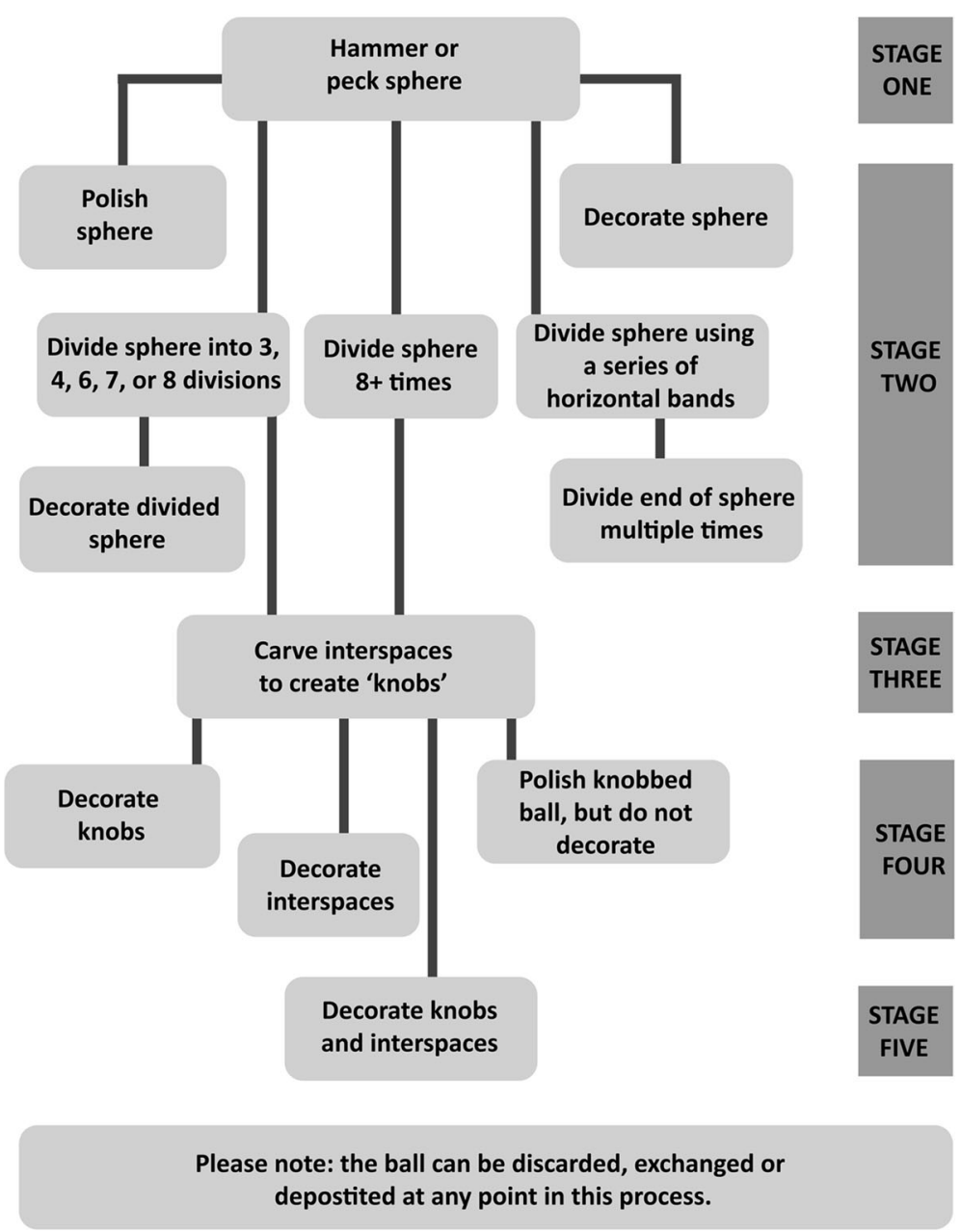

Fig. 3 An operational sequence for the manufacture of carved stone balls. Image: Hannah Sackett 
any of these artefacts as finished. Rather than viewing carved stone balls as representing the imposed form of Platonic solids (Critchlow 2007), we can in fact see that the forms simply arise from dividing a sphere (Reimann 2014; Lloyd 2012). This simple process of division gives rise to a multitude of forms (Lloyd 2012); division is instead a matter of mathematical exploration and experimentation.

This ongoing exploration of material, the process of taking shape, is generative; it produces new sculptural forms and new ways of engaging with materials. We can consider this now when we examine carved stone balls at a greater scale of analysis (Fig. 4). Carved stone balls have a distinctive geographical distribution, with a focus on Northeast Scotland. There are also regional clusters in Orkney and Argyll and the Western Isles and small groups found in Northern Ireland and northern England. An analysis of the geology of these artefacts shows that some of these artefacts must have been exchanged from the main regional centre in Northeast Scotland, but in each regional cluster many of them are locally made (Jones and Díaz-Guardamino 2019, 116-19). This does not seem to conform to the models of bidirectional gift exchange we know for other Neolithic artefacts (e.g. for polished stone axes; Bradley and Edmonds 1993). How are we to explain this? I argue that this pattern of exchange and local production equates to a form of knowledge transfer, or transmission of knowledge (Roddick and Stahl 2016).

In their discussion of prehistoric art from the British Isles written in 1951 Stuart Piggott and Glyn Daniel state of carved stone balls that "their use is wholly unknown." (Piggott and Daniel 1951, 14) Is it possible that rather than having a single unitary function or use, these artefacts have multiple functions, one of which is to teach?

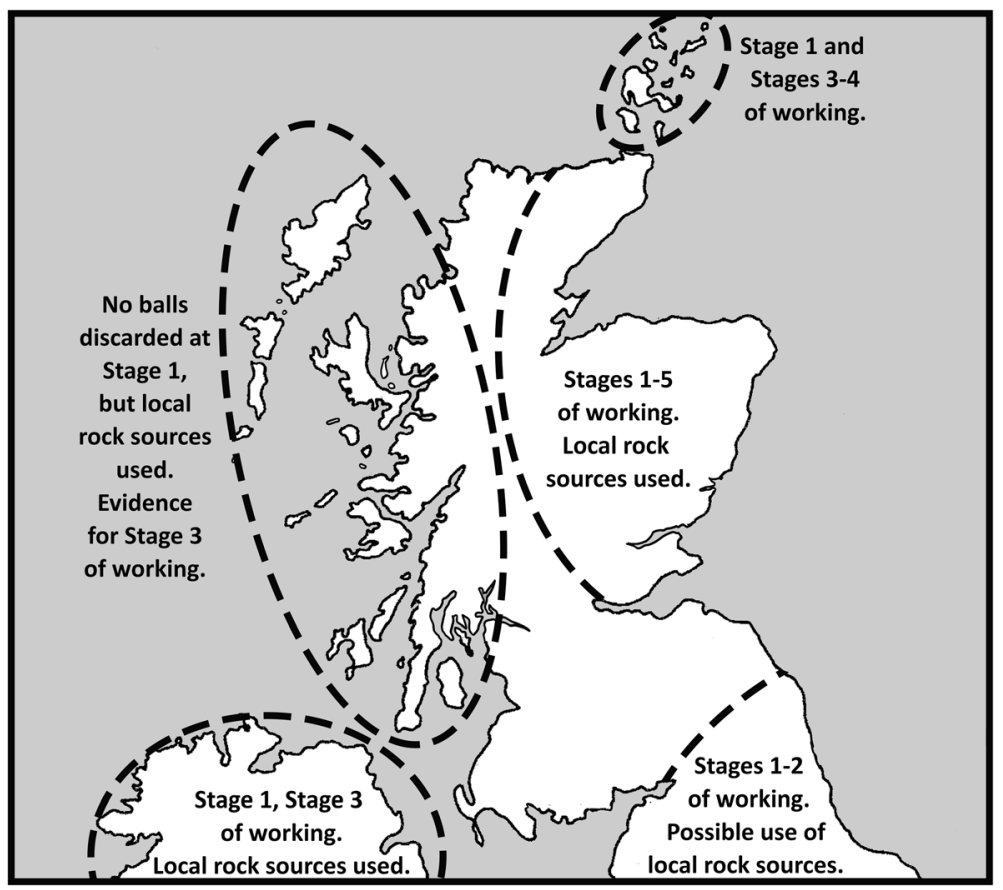

Fig. 4 Map showing the regional production and distribution of carved stone balls in Scotland, Northern Ireland and northern England. Image: Hannah Sackett 
Louisa Minkin and Ian Dawson (2014) also describe them as "object lessons." Carved stone balls are incomplete, artefacts-in-process, whose form embodies their processes of making. One of the key outcomes of an experimental workshop at Winchester School of Art focused on making carved stone balls, run by the author with Ian Dawson and Louisa Minkin, was the realisation that the manufacture of these objects involved a series of actions including hammering, polishing, pecking and fine working by incision (Jones 2016). It seems then that carved stone balls are potentially didactic objects, objects for learning the techniques of working stone. Drawing on the education scholar Elizabeth Ellsworth I find the term "pedagogical hinge" useful to describe carved stone balls (Ellsworth 2005, 37-56). Pedagogical hinges are pivot places or objects - things for knowing differently — in which the knowledge, thoughts and concepts of the learner are brought into relation with outside others; other events, histories, and social ideas. Pedagogical hinges are relationally dynamic. In the case of carved stone balls, working with materials, puzzling with materials, to work out how they were made unfolds a rich seam of knowledge relating to stone working, much of which will be applicable to other tasks whether manufacturing polished stone axes or mace heads or working architectural stone. In that sense, carved stone balls are affective artefacts: they make things happen. Each happening impacts upon others in a complex system of ongoing affective relations.

My analysis of carved stone balls emphasises a series of important aspects regarding affect: the making of carved stone balls is a process of encounter, or intra-action, in which the properties of stones are in dialogue with the capabilities of the craftsperson. Given the fact that many carved stone balls were discarded during the manufacture process it seems reasonable to argue that the outcomes of this encounter were unexpected and could produce a multitude of differing forms. The process of working was affective and effective, and involved the realisation of practical knowledge through skilful stone-working but simultaneously brought into focus new knowledge concerning the behaviour of stone under certain conditions of working. The practical encounter with stone was then also an affective process of learning, in which a variety of techniques of stone-working could be honed, and this knowledge was transferred and exchanged in the form of worked artefacts across Scotland, northern England and Northern Ireland. Carved stone balls are the product of affective encounters, while this encounter also produces affect in the form of skill, knowledge and learning.

It should be noted that the affects produced by working stone during the making of carved stone balls, are specific to this group of artefacts. Other kinds of working, with other kinds of materials, produced differing affects. My analysis of a suite of decorated artefacts from Neolithic Britain and Ireland indicates a series of differing encounters with materials produce quite different affects (Jones and Díaz-Guardamino 2019). For example, contemporary with carved stone balls, the working of slate artefacts on the Isle of Man (situated at the centre of the Irish Sea) was a lengthy process that involved the production of small stone plaques with the form of miniature polished stone axes. At some point in their lives these stone plaques were deliberately snapped and broken. After this, many of the stone plaques were decorated with fine curvilinear marks. This process was undertaken repeatedly, and earlier marks were often erased and carved over (Jones et al. 2016; Jones and Díaz-Guardamino 2019). The outcomes, or affects, of this practice of working was multiple, and the working of slate in this way connected the slate plaques to a multitude of other practices both in the Isle of Man, and in 
surrounding regions such as Ireland and Wales. The practices of making and decorating the plaques actively forged these series of connections (Jones et al. 2016, 16). Making carved stone balls and slate plaques assembled quite different sets of techniques, and differing materials, and these sets of relationships realised quite different capacities and outcomes (see also Jervis 2019, 43-44).

One of the reasons the study of affect is so interesting is that affects are multitudinous: each set of circumstances is associated with differing affects. For this reason, I find the study of affect superior to Gell's $(1992,1998)$ argument that artworks act as technologies of enchantment. This concept presupposes that artworks are indexes of human agency and ingenuity and seems to narrow the possible affective capacities of artworks. Instead, I find the open-ended approach to the study of affect particularly useful when considering the archaeology of art as it increases our ability to understand the potential of artworks. In the final section of the paper, I will discuss the advantages of this open-ended approach to the study of affect in archaeology and will outline what an archaeology of art focused on affect might look like.

\section{The Archaeology of Art: From Representation to Affect}

As I discussed at the beginning of the paper, definitions of "art" are fraught with problems. I have eschewed attempts to define "art" in the context of Neolithic Britain, largely because I believe that epistemological definitions involve the closing down of discussion; they are a way of reconstructing other visual cultures in the image of the West (Dean 2006, 27), of making other cultures behave according to prior expectations. My case study focused on the carved stone balls of Neolithic Scotland and instead of worrying whether these objects constituted "art" or "artefact," or whether they constituted symbols or technologies, my analysis instead focused on affect; on encounter and outcome. My analysis attended to the different affects realised as carved stone balls moved though differing sets of relations beginning with the relationship between maker and material during making, followed by the affects realised by the changing sets of relations involved in trade and exchange. During making, carved stone balls instantiated an experimental intra-action with materials, and this spirit of experimentation flowed into wider domains as the stone balls became objects for learning. My affectcentred analysis therefore side-stepped the question of definitions (are carved stone balls lithic technologies or examples of lithic art?) because I believe questions of definition are unhelpful in this context as they obscure the analysis of the capacities and effects of these artefacts. Having placed the study of affect front and centre in this paper I want to close by considering the concepts of affect and intra-action in a little more depth.

My discussion of affect diffracts the notion of sensation and affect developed by Gilles Deleuze (2003 [1981]) and Gilles Deleuze and Felix Guattari (2009 [1994]) through Karen Barad's concept of intra-action. In the following, I will tease apart these ideas and look at what they are able to offer archaeologists interested in the study of art, before recombining them at the close of the paper. Before doing this, we need to reconsider some philosophical problems associated with the study of art.

Traditional accounts of art in archaeology and anthropology are founded upon representationalist assumptions (for a fuller discussion of this, see Jones and Cochrane 
2018, 1-30). Representationalism is based upon the notion that the world is separated into ontologically distinct domains of words and matter. As part of this set of assumptions, representations are considered to mediate between knower and known; in this conception matter is mediated in a knowable form as words, representations or symbols. The idea that art is composed of representations or symbols whose most "salient attribute seem to be their ability to carry meaning" (Creese 2017, 643) is still commonplace in archaeology. Indeed, precisely one of the problems we face with the definition of art is that it is tacitly assumed to be representation-like. As representations, artworks are treated as distinct from matter and function. Artworks seem to be nonfunctional, how then are we to define them?; in this conception, art does not matter, because it is not of matter.

Of course, the idea that artworks as representations are distinct from matter is ridiculous. We know full well that artworks are composed of matter, paintings are made of pigments, canvas and frame, sculptures may be of bronze, marble or alabaster. However, representationalist accounts choose to focus on how artworks function as representations, rather than focusing on their matter. How then are we to incorporate a discussion of matter into our accounts of art? One-way of doing this is to explore the notion of intra-action between maker and materials in the making of artworks.

The concept of intra-action, proposed by Karen Barad (2003, 2007), was devised precisely to question the metaphysical assumptions on which representationalism is founded. Rather than their being prior distinctions between independent entities, like words and matter, the notion of agential intra-action proposes that the "boundaries and properties of the components of phenomena become determinate and ... particular concepts (that is, particular material articulations of the world) become meaningful" (Barad 2007, 139) through intra-action. In Barad's work, there is no prior distinction between words and matter. Thought and matter are conjoined. Intra-action is a helpful concept because it allows archaeologists to grasp the tangible moment of differentiation (see also Marshall and Alberti 2014); the moment at which maker and material compose each other. However, to understand the outcomes of this encounter further our account will be enriched by the concept of affect.

Gilles Deleuze, and Deleuze and Félix Guattari's, analysis of affect and sensation also offers an approach to art unencumbered by questions of representation. As Elizabeth Grosz $(2008,78)$ notes, in this conception:

"Art is not a self-contained activity in the sense that it is disconnected from the ways in which the natural and social worlds function. Art, however, is not a window onto these worlds, nor a mode of their representation ... Rather, it is where intensities proliferate, where forces are expressed for their own sake, where sensation lives and experiments, where the future is affectively and perceptually anticipated."

Art is not concerned with representation or the conveyance of meaning, it is concerned with summoning up sensations. Artworks are "not so much to be read, interpreted, deciphered as responded to, touched, engaged, intensified" (Grosz 2008, 79). The sensations realised by interacting (or intra-acting) with artworks produce affects. Affects are nebulous and can be understood as "impersonal intensities that do not belong to a subject or an object" (Anderson 2010, 161). Where are affects then, how do 
we comprehend them, and how do we make them available for archaeological analysis? The discussion of sensation and affect is helpful as it shifts the conversation away from imponderable archaeological topics in the archaeology of art, such as representation and meaning (for development of this argument, see Jones and Cochrane 2018, 1-30), and instead allow us to consider the bodily impact, or affect, ancient artworks had on the subject (here, there are parallels with phenomenological questions relating to the relationship between subject and world; Deleuze 2003 [1981], 25). The encounter between person and artwork, or subject and object, is key to our understanding here as it is through this encounter that sensations and affects are realised. Discussion of affect allows us to foreground what happens, perceptually, emotionally, and affectively in a state of relation.

The concept of agential intra-action and the concepts of sensation and affect begin with similar assumptions based on the notion of relationality. Rather than fixed entities pre-existing the relation, entities instead emerge through relationships. It is this relationship that the term 'intra-action' denotes, but this relation is also captured in Deleuze's (2003 [1981], 25, original emphasis) notion of sensation and affect: "Sensation has one face turned towards the subject ... and one towards the object. Or rather, it has no faces at all, it is both things indissolubly ... at one and the same time I become in the sensation and something happens in the sensation." Whereas intra-action captures a sense of the way in which phenomena become meaningful and determinate, the notions of sensation and affect allow us to describe the forces that lead to intra-actions and consider the possible outcomes of these encounters.

Affect allow us to move beyond representational accounts of art, whereas intraaction enables us to think about the way in which encounters are also processes of differentiating and marking. I believe that both concepts are essential to a re-description of an archaeology of art. Affect allows us to consider artworks in terms of impact, force and encounter, while intra-action allows us to understand how these forces leave a trace or mark, making them archaeologically legible.

Acknowledgements The research on carved stone balls in this paper benefited from a Leverhulme Trust award (RPG-2014-193). I would like to acknowledge the help of the participants in the Archaeologies of Media and Technology reading group, Winchester School of Art Spring 2019 amongst whom I have been reading Karen Barad's "Meeting the Universe Halfway." Thanks for your intelligence, scholarship and generosity.

Author Information Andrew Meirion Jones is Professor of Archaeology, University of Southampton, UK. Address: Archaeology, Faculty of Arts and Humanities, University of Southampton, Highfield, Southampton SO17 1BF, UK. Email: amj@ soton.ac.uk

Open Access This article is licensed under a Creative Commons Attribution 4.0 International License, which permits use, sharing, adaptation, distribution and reproduction in any medium or format, as long as you give appropriate credit to the original author(s) and the source, provide a link to the Creative Commons licence, and indicate if changes were made. The images or other third party material in this article are included in the article's Creative Commons licence, unless indicated otherwise in a credit line to the material. If material is not included in the article's Creative Commons licence and your intended use is not permitted by statutory regulation or exceeds the permitted use, you will need to obtain permission directly from the copyright holder. To view a copy of this licence, visit http://creativecommons.org/licenses/by/4.0/. 


\section{References}

Anderson, B. (2010). Modulating the excess of affect. Morale in a state of "total war". In M. Gregg \& G. J. Seigworth (Eds.), The affect theory reader (pp. 161-185). Durham, NC: Duke University Press.

Back Danielsson, I.-M., \& Jones, A. M. (Forthcoming). Images in the making. In Art-process-archaeology. Manchester: Manchester University Press.

Barad, K. (2003). Posthuman performativity: toward an understanding of how matter comes to matter. Signs. Journal of Women in Culture and Society, 28(3), 801-831.

Barad, K. (2007). Meeting the universe halfway. Quantum physics and the entanglement of matter and meaning. Durham, NC: Duke University Press.

Barad, K. (2013). Matter feels, converses, suffers, desires, yearns and remembers interview with Karen Barad. In R. Dolphijn \& I. van der Tuin (Eds.), New materialism: interviews and cartographies (pp. 48-70). Ann Arbor, MI: Open Humanities Press.

Bradley, R. and Edmonds, M. (1993) Interpreting the Axe Trade. Production and Exchange in Neolithic Britain. Cambridge: Cambridge University Press.

Brady, L., \& Bradley, J. J. (2016). 'Who do you want to kill?': affectual and relational understandings of a sorcery rock art site in the southwest Gulf of Carpentaria, northern Australia. Journal of the Royal Anthropological Institute, 22(4), 884-901.

Childe, V. G. (1931). Skara Brae: a Pictish village in Orkney. London: Kegan Paul.

Clarke, D.V., Cowie, T.G. and Foxon, A. (1985) Symbols of Power at the Time of Stonehenge. Edinburgh: HMSO.

Colman, F. (2005). Affect. In A. Parr (Ed.), The Deleuze dictionary (Revised ed., pp. 11-13). Edinburgh: Edinburgh University Press.

Creese, J. (2017). Art as kinship: signs of life in the eastern woodlands. Cambridge Archaeological Journal, 27(4), 643-654.

Critchlow, K. (2007). Time stands still. New light on megalithic science. Edinburgh: Floris Books.

Dean, C. (2006). The trouble with (the term) art. Art Journal, 65(2), 24-32.

DeMarrais, E. (2017). Animacy, abstraction and affect in the Andean past: towards a relational approach to art. Cambridge Archaeological Journal, 27(4), 655-669.

Deleuze, G. (2003 [1981]). Francis bacon: the logic of sensation. Trans. Daniel W. Smith. London: Continuum.

Deleuze, G. and Guattari, F. (2009 [1994]). What is philosophy. Trans. G. Burchell and H. Tomlinson. London: Verso.

Dobres, M.-A., \& Robb, J. (2000). Agency in archaeology. London: Routledge.

Ellsworth, E. (2005). Places of learning: media, architecture, pedagogy. London: Routledge.

Evans, J. (1897). Ancient stone implements. Weapons and ornaments of Great Britain. London: Longmans, Green and Co.

Fariss Thompson, R. (1973). Yoruba art criticism. In W. D'Azevedo (Ed.), The traditional artist in African societies (pp. 19-61). Bloomington: Indiana University Press.

Gell, A. (1992). The technology of enchantment and the enchantment of technology. In J. Coote \& A. Shelton (Eds.), Anthropology, art and aesthetics (pp. 40-63). Oxford: Clarendon.

Gell, A. (1998). Art and agency. An anthropological theory. Oxford: Clarendon Press.

Gosden, C. (2001). Making sense: archaeology and aesthetics. World Archaeology, 33(2), 163-167.

Gregg, M., \& Seigworth, G. (2010). An inventory of shimmers. In M. Gregg \& G. Seigworth (Eds.), The affect theory reader (pp. 1-25). ) Durham, NC: Duke University Press.

Grosz, E. (2008). Chaos, territory, art. In Deleuze and the framing of the earth. New York: Columbia University Press.

Guattari, F. (2000 [1989]). The three ecologies. Translated by Ian Pindar and Paul Sutton. London: Bloomsbury.

Hamilakis, Y. (2013). Archaeology and the senses: human experience, memory and affect. Cambridge: Cambridge University Press.

Harris, O., \& Sørenson, T. F. (2010). Rethinking emotion and material culture. Archaeological Dialogues, 17(2), 145-163.

Ingold, T. (2013). Making. In Anthropology, archaeology, art, architecture. London: Routledge.

Jervis, B. (2019). Assemblage thought and archaeology. London: Routledge.

Jones, A. M. (2016). Making carved stone balls: art, experimental practice and archaeological research. In H. Chittock \& J. Valdez-Tullett (Eds.), Archaeology with art (pp. 1-12). Oxford: Archaeopress.

Jones, A. M. (2017). Rock art and ontology. Annual Review of Anthropology, 46(1), 167-181. 
Jones, A. M. (Forthcoming). Art before Plato: the carved stone balls of Northeast Scotland. In I.-M. B. Danielsson \& A. M. Jones (Eds.), Images in the making. Art, process, archaeology. Manchester: Manchester University Press.

Jones, A. M., Díaz-Guardamino, M., \& Crellin, R. J. (2016). From artefact biographies to 'multiple objects': a new analysis of the decorated plaques of the Irish Sea region. Norwegian Archaeological Review, 49(2), $1-21$.

Jones, A. M., \& Cochrane, A. (2018). The archaeology of art. In Materials, practices, affects. London: Routledge.

Jones, A. M., \& Díaz-Guardamino, M. (2019). Making a mark: image and process in Neolithic Britain and Ireland. Oxford: Oxbow.

Kubler, G. (1962). The shape of time. In Remarks on the history of things. New Haven, Conn: Yale University Press.

Lawlor, R. (2002). Sacred geometry: philosophy and practice. London: Thames and Hudson.

Lloyd, D. R. (2012). How old are the platonic solids? BHSM Bulletin: Journal of the British Society for the History of Mathematics, 27(3), 131-140.

Mann, L. M. (1915). Archaic sculpturings: notes on art, philosophy and religion in Britain 2000 BC to 900 $A D$. Edinburgh: Hodges.

MacGregor, G. (1999). Making sense of the past in the present: a sensory analysis of carved stone balls. World Archaeology, 31(2), 258-271.

Marshall, D. (1977). Carved stone balls. Proceedings of the Society of Antiquaries of Scotland, 108, 40-72.

Marshall, D. (1983). Further notes on carved stone balls. Proceedings of the Society of Antiquaries of Scotland, 113, 628-646.

Marshall, Y., \& Alberti, B. (2014). A matter of difference: Karen Barad, ontology and archaeological bodies. Cambridge Archaeological Journal, 24(1), 19-36.

Minkin, L., \& Dawson, I. (2014). Object lessons: copying and reconstruction as a teaching strategy. Art, Design and Communication in Higher Education, 13(1), 19-29.

Morphy, H. (1992). From dull to brilliant: the aesthetics of spiritual power among the Yolngu. In J. Coote \& A. Shelton (Eds.), Anthropology, art and aesthetics (pp. 181-208). Oxford: Clarendon Press.

Morphy, H. (2009). Art as a mode of action: some problems with Gell's art and agency. Journal of Material Culture, 14(1), 5-26.

O'Sullivan, S. (2006). Art encounters. In Deleuze and Guattari: thought beyond representation. New York: Palgrave Macmillan.

Pattison, J. (2012). Models of mind: carved stone balls from the islands of Scotland. Taigh Chearsabhagh Museum and Arts Centre.

Piggott, S., \& Daniel, G. (1951). A picture book of ancient British art. Cambridge: Cambridge University Press.

Porr, M. (2019). Rock art as art. Time and Mind, 12(2), 153-164.

Ravilious, K. (2010). Stonehenge built with balls? Available at http://news.nationalgeographic. com/news/2010/12/101210-stonehenge-balls-ball-bearings-science-rolled/.

Reimann, D. A. (2014). Art and symmetry of Scottish carved stone balls. Proceedings of Bridges 2014: Mathematics, Music, Art, Architecture, Culture (pp. 441-444).

Robb, J. (2017). 'Art' in anthropology and archaeology: an overview of the concept. Cambridge Archaeological Journal, 27(4), 587-597.

Roddick, A. P., \& Stahl, A. B. (2016). Knowledge in motion: constellations of learning across time and place. Tucson, AZ: University of Arizona Press.

Seigworth, G. (2017). Capaciousness, Capacious: Journal for Emerging Affect Inquiry 1(1), i-v. http:// capaciousjournal.com/cms/wp-content/uploads/2017/07/seigworth-capaciousness.pdf. .

Sjöstrand, Y. (2017). The concept of art as archaeologically applicable. Cambridge Archaeological Journal, 27(2), 371-388.

Stewart, K. (2007). Ordinary affects. Durham, NC: Duke University Press.

Todd, T. N. (2006). The aerodynamics of carved stone balls. Proceedings of the Society of Antiquaries of Scotland (Vol. 136, pp. 61-74).

Publisher's Note Springer Nature remains neutral with regard to jurisdictional claims in published maps and institutional affiliations. 